\title{
PENGEMBANGAN MEDIA PEMBELAJARAN MENGGUNAKAN MODEL CAI SEBAGAI UPAYA MEMPERBAIKI KUALITAS PEMBELAJARAN PADA MATA KULIAH FISIKA OPTIK
}

\author{
Euis Ismayati \\ Dosen Jurusan Teknik Elektro Fakultas Teknik UNESA
}

\begin{abstract}
ABSTRAK : Penelitian ini bertujuan mengembangkan produk media pembelajaran dengan bantuan komputer pada materi Fisika Optik untuk mahasiswa S-1 Teknik Elektro, mengetahui perbedaan hasil belajar mahasiswa yang menggunakan media pembelajaran dengan hasil belajar mahasiswa yang tidak menggunakan media pembelajaran, dan untuk mengetahui respon mahasiswa terhadap media pembelajaran dengan bantuan komputer. Penelitian dilakukan dalam dua tahap: 1) Tahap penelitian pendahuluan, yaitu penelitian pengembangan dilakukan untuk mengembangan produk media pembelajaran interaktif Fisika Optik. 2) Penelitian lanjutan dengan menggunakan metode penelitian tindakan kelas, langkah-langkahnya menggunakan model Lewin. Penelitian terdiri dari empat siklus, dimana peneliti sebagai guru dan sekaligus instrumen penelitian. Hasil penelitian menunjukkan, bahwa produk media pembelajaran yang dikembangkan cukup menarik minat mahasiswa, yang ditunjukkan dari meningkatnya hasil belajar mahasiswa dan respon positif dari mahasiswa.
\end{abstract}

Kata kunci : Media pembelajaran, CAI, hasil belajar.

\begin{abstract}
This research aims to develop instructional media products with the computer based instructions in Physics Optical subject matter for S1 Electrical Engineering students, know the difference learning outcomes between students who use instructional media and students who do not use instructional media, and to study the response of students to instructional media with computer based instructions. The research was conducted in two stages: 1) preliminary research stage, research and development which is carried out to develop an interactive instructional media products for Optical Physics. 2) Further research using action research class method, the steps using the model of Lewin. The research consisted of four cycles, in which researcher as a teacher as well as research instruments. The results showed that the instructional media products that are developed enough to attract students which is indicated from the increase of learning outcomes and positive response from students.
\end{abstract}

Keyword : instructional media products, CAI, learning outcomes

\section{PENDAHULUAN}

Mata kuliah Fisika merupakan mata kuliah yang dapat menunjang mata kuliah kejuruan di Jurusan Teknik Elektro FT UNESA, sehingga kualitas 
pembelajarannya harus lebih ditingkatkan. Berdasarkan pengalaman peneliti sebagai dosen pengajar Fisika, mahasiswa masih sulit memahami pokok bahasan yang bersifat analisis dan cenderung pasif, serta rendahnya keterampilan mahasiswa dalam memecahkan masalah.

Pembelajaran dengan bantuan komputer dapat digunakan sebagai media pembelajaran berbasis ICT karena komputer mempunyai berbagai manfaat antara lain: (1) mampu menyimpan data, (2) mampu menghitung dengan cepat dan tepat, (3) dapat melakukan pekerjaan berulang-ulang kali sesuai dengan keinginan pemakai, (4) dan mampu menampilkan bentuk grafik, bagan, gambar serta suara.

Berdasarkan hasil penelitian sebelumnya yaitu hasil penelitian Darmawan (2007) tentang pengembangan media dengan macromedia, menyatakan terdapat kemudahan dalam penggunaan media interaktif mencapai $75 \%$, sedangkan kesesuaian dan kemenarikan media pembelajaran mencapai 68,75\%.

Berdasarkan masalah tersebut perlu dikembangkan media pembelajaran dengan model Computer Assited Instruction (CAI) untuk mengurangi keterbatasan alat yang terdapat pada laboratorium. Media yang dibuat berupa CD media pembelajaran yang didalamnya berupa materi pembelajaran dan simulasi serta terdapat evaluasi yang digunakan untuk mengukur pemahaman mahasiswa tentang materi yang disampaikan.

\section{KAJIAN PUSTAKA}

\section{Pembelajaran dengan Bantuan Komputer atau Computer Assisted Instruction} (CAI)

Menurut Arsyad (1996) sistem-sistem komputer dapat menyampaikan pengajaran secara langsung kepada para siswa melalui cara berinteraksi dengan mata pelajaran yang diprogramkan ke dalam sistem. Inilah yang disebut pembelajaran dengan bantuan komputer atau Computer-Assited Instruction (CAI). Ada berbagai macam kemungkinan penggunaan CAI, meliputi model-model mengajar sehingga komputer dapat memberikan kemudahan paling efektif, misalnya sebagai tutorial, latihan dan praktik, penemuan, simulasi, dan permainan. 
Faktor pendukung keberhasilan CAI menurut Arsyad (1996) bergantung kepada beberapa faktor seperti proses kognitif dan motivasi dalam belajar. Oleh karena itu, para ahli telah mencoba mengajukan prinsip-prinsip perancangan CAI yang diharapkan bisa melahirkan program CAI yang efektif dan menyenangkan.

Meskipun pembelajaran dengan komputer dapat dipandang efektif, namun terdapat beberapa kekuatan dan keterbatasan khususnya penggunaannya untuk tujuan-tujuan pendidikan. Arsyad (2003) dan Sadiman (1986) mengemukakan keuntungan dan keterbatasan penggunaan komputer sebagai berikut:

Keuntungan penggunaan komputer:

- Komputer dapat mengakomodasi siswa yang lamban menerima pelajaran, karena ia dapat memberikan keefektifan dalam pembelajaran dengan cara yang lebih individual, tidak pernah lupa, tidak pernah bosan, sangat sabar dalam menjalankan instruksi seperti yang diinginkan program yang digunakan.

- Komputer dapat merangsang siswa untuk mengerjakan latihan, melakukan kegiatan laboratorium atau simulasi karena tersedianya animasi grafik, warna, dan musik yang dapat menambah realisme.

- Kendali berada di tangan siswa sehingga tingkat kecepatan belajar siswa dapat disesuaikan dengan tingkat penguasaannya. Komputer dapat berinteraksi dengan siswa secara perorangan misalnya dengan bertanya dan menilai jawaban.

- Kemampuan merekam aktivitas siswa selama menggunakan suatu program pembelajaran memberi kesempatan lebih baik untuk pembelajaran secara perorangan dan perkembangan setiap siswa selalu dapat dipantau.

- Dapat dihubungkan dan mengendalikan peralatan lain seperti compact disk, video tape, flash disk, dan lain-lain.

Keterbatasan-keterbatasan penggunaan komputer:

- Meskipun harga perangkat keras komputer cenderung semakin menurun (murah), pengembangan perangkat lunaknya masih relatif mahal.

- Untuk menggunakan perangkat komputer diperlukan pengetahuan dan ketrampilan khusus tentang komputer. 
- Keragaman model komputer (perangkat keras) sering menyebabkan program (software) yang tersedia untuk satu model tidak cocok (kompatibel) dengan model lainnya.

\section{Strategi Pemanfaatan Media}

Sadiman dkk (2009:197) mengemukakan strategi pemanfaatan media agar dapat digunakan secara efektif dan efisien, yaitu:

1. Persiapan sebelum menggunakan: Supaya penggunaan media dapat berjalan baik kita perlu membuat persiapan yang baik pula. Pertama-tama pelajari petunjuk yang ada. Apabila pada petunjuk disarankan untuk membaca buku yang sesuai dengan tujuan yang akan dicapai seyogyanya hal tersebut dilaksanakan. Hal tersebut akan memudahkan kita dalam belajar dengan media itu.

2. Kegiatan selama menggunakan media: Yang perlu dijaga selama kita menggunakan media ialah suasana ketenangan. Gangguan-gangguan yang dapat mengganggu perhatian dan konsentrasi harus dihindarkan.

3. Kegiatan tindak lanjut: Maksud kegiatan tindak lanjut ini ialah untuk menjajagi apakah tujuan telah tercapai. Selain itu, untuk memantapkan pemahaman terhadap materi yang disampaikan melalui media. Untuk itu soal tes yang disediakan perlu kita kerjakan dengan segera sebelum kita lupa isi program media itu.

\section{Materi Fisika Optik}

Sesuai Garis Besar Rencana Perkuliahan (GBRP) materi Fisika Optik meliputi:Sifat dan perambatan cahaya, pemantulan cahaya, pembiasan cahaya, interferensi, dispersi dan difraksi cahaya.

1. Sifat dan Penjalaran Cahaya: Pada materi ini dijelaskan mengenai pengertian cahaya, sifat cahaya, sumber cahaya, berkas cahaya dan prinsip Huygens.

2. Pemantulan Cahaya: Pada materi ini dijelaskan mengenai jenis-jenis pemantulan cahaya, hukum pemantulan cahaya, melukis pembentukan bayangan pada cermin datar dan cermin lengkung, menentukan sifat 
bayangan dan menentukan hubungan jarak benda, jarak fokus dan jarak bayangan.

3. Pembiasan Cahaya: Pada materi ini dijelaskan mengenai pengertian pembiasan, hukum pembiasan cahaya, indeks bias medium, pembiasan pada medium optik kurang rapat dan lebih rapat, pemendekan semu dan pemanjangan semua akibat pembiasan serta pemantulan total.

4. Dispersi, Interferensi, dan Difraksi Cahaya: Pada materi ini dijelaskan mengenai dispersi cahaya, perbedaan fase dan koherensi fase, interferensi pada lapisan tipis, interferensi dua celah dan difraksi celah tunggal.

\section{METODE}

Penelitian ini dilakukan dalam dua tahapan, yaitu penelitian pendahuluan dan penelitian lanjutan.Pada penelitian pendahuluan merupakan tahap pengembangan produk berupa perangkat media pembelajaran Fisika Optik yang dikemas dalam bentuk CD interaktif.Sedangkan penelitian lanjutan merupakan penelitian tindakan kelas (action research).

\section{Penelitian Pengembangan (Penelitian Pendahuluan)}

\section{a. Pengembangan Produk Pembelajaran}

1) Survei lapangan: Pengumpulan data melalui wawancara dan pengamatan meliputi: (a) metode pembelajaran yang digunakan pada materi Fisika Optik, (b) pengamatan peralatan laboratorium Fisika.

2) Studi kepustakaan: Studi kepustakaan meliputi: (a) Landasan teori tentang media pembelajaran, (b) Media pembelajaran dengan berbantuan computer. (c) Hasil-hasil penelitian yang terdahulu yang menggunakan media pembelajaran dengan model CAI.

3) Design produk: Produk yang dihasilkan berupa media pembelajaran dengan bantuan komputer. Format media pembelajaran yang akan dibuat ini diarahkan ke format sajian Tutorial. Dibuat dalam sebuah flowchart terdiri dari: (a) Panduan, berisi tentang petunjuk penggunaan media. (b) Materiberisi Fisika Optik meliputi: sifat dan penjalaran cahaya, pemantulan cahaya, pembiasan cahaya, dispersi, interferensi, dan 
difraksi cahaya.dan (c) Soal evaluasi, tes yang digunakan berbentuk objektif yaitu berupa pilihan ganda (multiple choice) pada setiap akhir penyajian materi (sub pokok bahasan Optik) dan soal evaluasi akhir (pokok bahasan Optik).

\section{Prosedur Pengembangan Produk}

Pengembangan perangkat pembelajaran model CAI mengacu pada model rancangan pembelajaran Conductive (Ismayati, 2009) yang diikuti dengan eksperimen pada ujicoba lapangan, sehingga metode yang digunakan adalah metode penelitian dan pengembangan (Research and Development atau R \& D). Pengembangan produk ini telah dilakukan pada penelitian pendahuluan (Rochim, 2010). Model pengembangan pembelajarannya seperti pada gambar 1 berikut:

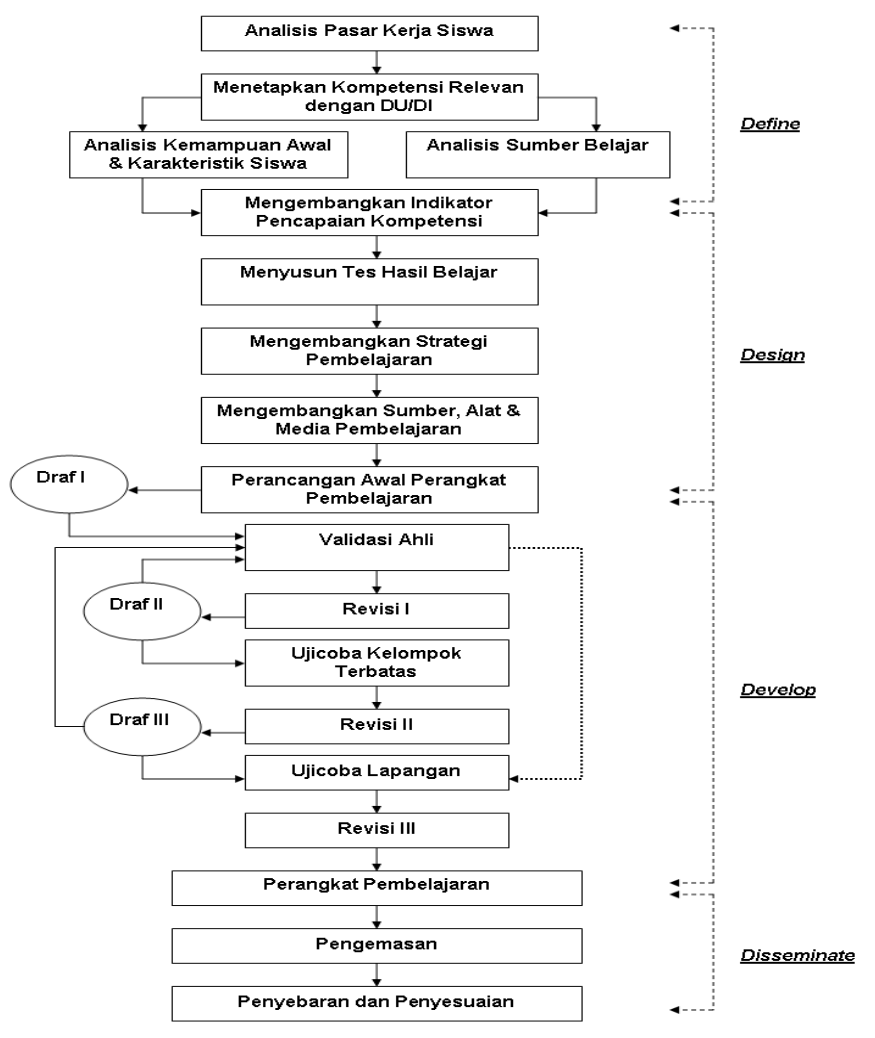

Gambar 1. Model Pengembangan Pengajaran Conductive

Prosedur untuk mengembangkan perangkat pembelajaran dengan model conductive, meliputi: 
1) Menetapkan materi pelajaran yang dikembangkan: Masalah utama dalam pembelajaran Fisika adalah tidak tersedianya alat-alat peraga atau alat praktek fisika, maka ditetapkan materi pelajaran yang akan dikembangkan yaitu materi Fisika Optik.

2) Menentukan langkah-langkah pengembangan, yaitu: (a) Tahap Define (Pendefinisian), (b) Tahap Design (Perancangan). (c) Tahap Develop (Pengembangan). (d) Tahap Disseminate (Penyebaran), pada pengembangan ini peneliti tidak melakukan tahapan disseminate, tetapi hanya sampai pada tahapan develop.

\section{Ujicoba Produk}

1) Validasi Ahli: validasi merupakan masukan-masukan untuk perbaikan produk yang dikembangkan, berupa penilaian, komentar, saran, dan kritik yang bersifat perbaikan dan penyempurnaan produk. Validator terdiri dari: ahli isi, ahli media, ahli desain, dan ahli bahasa.

2) Ujicoba Kelompok Kecil (Ujicoba Terbatas): ujicoba kelompok terbatas dilaksanakan pada 6 orang mahasiswa jurusan Teknik Listrik semester 2. Ujicoba ini sangat perlu dilakukan dengan pertimbangan mahasiswa akan memiliki pertimbangan yang berbeda dalam menilai produk yang dikembangkan, karena merekalah yang akan memakai dan menggunakan produk pembelajaran.

3) Ujicoba Lapangan: ujicoba lapangan dilaksanakan pada 2 kelas, 60 mahasiswa jurusan Teknik Listrik, terdiri dari 1 kelas kontrol (30 orang) dan 1 kelas eksperimen (30 orang).

\section{Penelitian Tindakan Kelas (Penelitian Lanjutan)}

\section{a. Tahap Perencanaan Tindakan Kelas}

Pada pembelajaran Fisika ini peneliti sebagai guru (dosen), sehingga peneliti secara langsung dapat mengamati perkembangan kemajuan mahasiswa selama pembelajaran berlangsung.

1) Menentukan Fokus Masalah: Melalui identifikasi masalah ditemukan: (a) kurangnya sarana praktikum untuk mata kuliah Fisika, (b) Sulitnya mahasiswa 
memahami pokok bahasan yang bersifat analisis, sehingga laporan hasil praktikum sering berbeda dengan hasil hitungan atau analisis. (c) Rendahnya keterampilan mahasiswa dalam memecahkan masalah dan cenderung pasif. (d) Hasil belajar yang kurang memuaskan. Hal ini menunjukan masih perlunya inovasi pembelajaran dalam upaya meningkatkan kualitas proses pembelajaran, baik bagi mahasiswa maupun dosen, dan peningkatan hasil nilai akhir mahasiswa. Penelitian difokuskan pada peningkatan kualitas pembelajaran dengan memperbaiki proses pembelajaran, yaitu dengan cara membuat modul pembelajaran tutorial dalam CD interaktif.

2) Menentukan Instrumen Penelitian: Dosen pengajar Fisika merupakan alat atau instrumen yang peka terhadap gejala yang ditimbulkan oleh subyek yang diteliti. Pengajar dapat merasakan secara langsung kekurangan dan kelebihan dari suatu kegiatan proses belajar mengajar yang sedang berlangsung, sehingga dosen menjadi instrumen dalam penelitian tindakan kelas. Sedangkan tim dosen lainnya, berpartisipasi sebagai mitra dalam penelitian.

3) Merencanakan Langkah-langkah Penelitian: Dalam penelitian ini merujuk pada "Model Lewin yang ditafsirkan oleh Kemmis" (lihat gambar 2). Model Lewin menggambarkan beberapa siklus kegiatan berupa spiral. Pada awal kegiatan mengidentifikasi gagasan awal, melakukan recognaissance, menyusun rencana umum, mengembangkan rencana umum, menyusun rencana tindakan-tindakan, mengimplementasikan langkah tindakan pertama, mengevaluasi, dan memperbaiki rancangan umum (Wiriaatmadja, 2005:62).

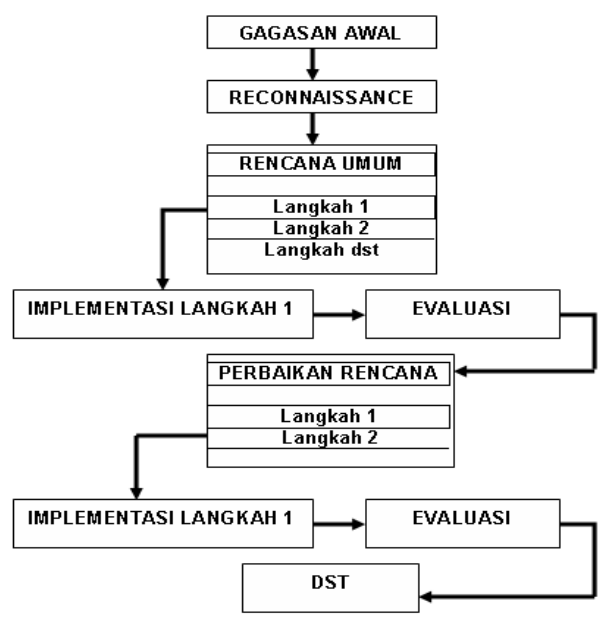

Gambar 2. Model Lewin yang Ditafsirkan Oleh Kemmis (Wiriaatmadja, 2005) 


\section{b. Tahap Pelaksanaan Tindakan Kelas}

Pelaksanaan tindakan kelas dilakukan sesuai dengan model Lewin, yaitu: 1) Siklus Pertama:

Pada tahap pertama peneliti mendiskusikan dengan tim dosen fisika tentang beberapa masalah pembelajaran fisika yang dihadapi oleh dosen dan mahasiswa. Selanjutnya dilakukan pengamatan terhadap aktivitas mahasiswa pada pembelajaran fisika yang sedang dan telah berlangsung. Masalah difokuskan pada peningkatan kualitas pembelajaran Fisika Optik dengan cara membuat modul pembelajaran tutorial dengan menggunakan komputer (CAI). Kemudian disusun rencana umum untuk mengembangkan langkah-langkah atau tindakan yang akan dilakukan. Tindakan yang akan dilakukan disesuaikan dengan materi yang akan dibahas terdiri dari 4 sub-pokok bahasan yaitu: (a) Sifat dan Penjalaran Cahaya, (b) Pemantulan Cahaya, (c) Pembiasan Cahaya, dan (d) Dispersi, Interferensi, dan Difraksi Cahaya.

Tindakan pertama membahas materi 1: Sifat dan Penjalaran Cahaya dengan menggunakan CD tutorial, tempat di laboratorium komputer jurusan Teknik Elektro, pada satu kelas mahasiswa program studi S1 kelas A angkatan 2010 dan dilaksanakan secara optimal sampai menemukan kesimpulan untuk segera dievaluasi. Kekurangan-kekurangan media animasi yang ditampilkan pada siklus pertama, kemudian diperbaiki sesuai dengan permasalahan yang ada. Perbaikan media dilakukan secara intensif, karena materi selanjutnya akan segera diujicobakan kepada mahasiswa pada pertemuan berikutnya.

2) Siklus kedua

Peneliti mendiskusikan pelaksanaan pembelajaran dengan tim dosen fisika berdasarkan pengalaman peneliti sebagai dosen dalam menyampaikan pelajaran dengan menggunakan Model CAI. Berdasarkan pengalaman, diharapkan tim dosen telah menemukan pola mengajar yang baik dalam menyusun materi pelajaran, menyesuaikan materi dengan waktu yang tersedia, menyesuaikan model mengajar dengan waktu yang tersedia, mengenal karakteristik mahasiswa dalam menghadapi pembelajarannya.

Kekurangan-kekurangan pada materi 1, dijadikan acuan untuk memperbaiki materi 2. Setelah materi 1 dan materi 2 direvisi, selanjutnya pada 
siklus kedua ini membahas materi 2: Pemantulan Cahaya. Dilakukan pengamatan terhadap aktivitas mahasiswa dan responnya terhadap pembelajaran melalui wawancara.Wawancara dilakukan kepada beberapa mahasiswa yang dianggap dapat memberikan masukan yang berarti sesuai dengan masalah dan tujuan penelitian.

3) Siklus ketiga

Dengan berbekal pada pengalaman pertama dan kedua, peneliti mengadakan diskusi dengan tim dosen fisika untuk menentukan langkah-langkah yang sesuai dengan masalah-masalah yang timbul baik dari pihak dosen maupun dari pihak mahasiswa. Pada tahap ketiga ini diharapkan dosen pengajar telah menemukan strategi pembelajaran yang sesuai dengan kebutuhan mahasiswa, kebutuhan materi pelajaran, dan sasaran pembelajaran sesuai dengan tujuan penelitian. Dengan demikian dosen pengajar diharapkan telah mampu melakukan pembelajaran dengan model CAI. Kekurangan-kekurangan pada materi 2 dijadikan rujukan pada materi berikutnya (materi 3), dan setelah materi 2 direvisi maka dilakukan pembahasan untuk materi 3: Pembiasan Cahaya. Dilakukan pengamatan terhadap aktivitas mahasiswa dan responnya terhadap pembelajaran melalui wawancara.Wawancara dilakukan kepada beberapa mahasiswa yang dianggap dapat memberikan masukan yang berarti sesuai dengan masalah dan tujuan penelitian.

4) Siklus keempat

Hasil diskusi pada tahap ketiga, akan menentukan langkah yang akan dilakukan pada tahap keempat. Dilakukan diskusi kembali dengan tim dosen fisika tentang perlunya perbaikan-perbaikan dalam pelaksanaan model pembelajaran. Diharapkan tim dosen dapat mengaplikasikan model pengajaran CAI pada mata kuliah lainnya. Kekurangan-kekurangan pada materi 3 dijadikan rujukan pada materi berikutnya (materi 4), dan setelah materi 3 direvisi maka dilakukan pembahasan untuk materi 4: Dispersi, Interferensi, dan Difraksi Cahaya.Dilakukan pengamatan terhadap aktivitas mahasiswa dan responnya terhadap pembelajaran melalui wawancara.Wawancara dilakukan kepada beberapa mahasiswa yang dianggap dapat memberikan masukan yang berarti sesuai dengan masalah dan tujuan penelitian. 
Siklus keempat merupakan siklus akhir dalam penelitian tindakan kelas pada pembelajaran Fisika Optik dengan menggunakan media animasi. Diharapkan model pembelajaran CAI dapat meningkatkan motivasi,dan hasil belajar mahasiswa. Temuan-temuan yang diperoleh merupakan hasil temuan penelitian tindakan kelas yang sangat berarti dalam penelitian ini.

\section{c. Tahap Observasi dan Evaluasi}

Peneliti sendiri sebagai dosen pengajar fisika Optik, maka observasi dilakukan pada saat pembelajaran fisika berlangsung dengan materi yang lainnya. Pada tahap observasi ini peneliti memperhatikan fokus penelitian pada kegiatan umum dan kegiatan khusus. Kegiatan umum meliputi pembelajaran teori fisika di dalam kelas dan praktek di laboratorium, sedangkan kegiatan khusus meliputi pembelajaran fisika khususnya pada pembelajaran fisika Optik dengan menggunakan media animasi.

Tahap evaluasi dilakukan setelah seluruh kegiatan observasi atau pengamatan dilakukan. Berdasarkan hasil observasi ini dapat diketahui kesalahankesalahan atau kekurangan-kekurangann pada pelaksanaan proses pembelajaran untuk selanjutnya dilakukan perbaikan-perbaikan.

\section{d. Tahap Refleksi (Perenungan)}

Perenungan merupakan kajian yang harus dilakukan setelah selesai melakukan pengamatan di lapangan. Kegiatan ini meliputi hal-hal yang perlu diperbaiki untuk meningkatkan kualitas media pembelajaran, proses belajar mengajar, dan sarana dan prasarana yang mendukung terhadap kelangsungan pelaksanaan pembelajaran.

\section{e. Subyek Penelitian, Waktu dan Lokasi Penelitian}

Subyek penelitian adalah 42 orang mahasiswa program studi S1 angkatan 2010 kelas A Jurusan Teknik Elektro. Lokasi penelitian di Jurusan Teknik Elektro Fakultas Teknik Kampus UNESA. Sedangkan penelitian tindakan kelas dilaksanakan pada awal semester gasal 20 September - 4 Oktober 2010. 


\section{f. Teknik Pengumpulan Data}

1) Observasi: Observasi di lingkungan kelas yaitu di dalam kelas teori dan laboratorium.

2) Wawancara: Wawancara dilakukan terhadap 20 orang mahasiswa prodi S1 angkatan 2010 jurusan Teknik Elektro UNESA, seorang teknisi laboratorium fisika, dan seorang dosen Fisika sebagai tim pengajar.

3) Rekaman foto pada saat proses pembelajaran CAI.

4) Catatan harian yang merekam semua kegiatan penelitian.

\section{g. Teknik Analisis Data}

Data yang telah diperoleh kemudian dianalisis sesuai dengan sifat data dan tujuan penelitian.Data observasi, data wawancara, dan catatan harian dideskripsikan, dilakukan reduksi data, dan ditayangkan dalam bentuk laporan.

\section{HASIL DAN PEMBAHASAN}

Hasil penelitian tindakan kelas diperoleh berdasarkan pada rancangan penelitian yang telah dilaksanakan. Hasil penelitian meliputi: 1) Pengembangan produk (penelitian pendahuluan), 2) Tahap pelaksanaan tindakan kelas, dan 3) Hasil belajar mahasiswa.

Pada tahap pelaksanaan tindakan kelas terdiri dari empat siklus yaitu siklus pertama, siklus kedua, siklus ketiga, dan siklus keempat.Tiap siklus memiliki keaktifan pembelajaran yang berbeda, sehingga respon mahasiswapun berbeda, tetapi hasil pembelajaran menunjukkan peningkatan dan perbaikan.

1. Siklus Pertama: Ujicoba media pembelajaran Fisika Optik menampilkan materi 1 yaitu Sifat dan Penjalaran Cahaya, berdasarkan hasil wawancara dengan 5 orang mahasiswa diperoleh hasil akhir yang berkaitan dengan perangkat media pembelajaran dan respons mahasiswa dideskripsikan sebagai berikut: Perangkat Media Pembelajaran, musik yang ditampilkan terlalu slow, kurang bersemangat. Selain itu tulisan-tulisan pada kotak materi jenis hurufnya tidak konsisten, atau bermacam-macam karakter.

Berdasarkan hasil wawancara dengan 3 orang mahasiswa diperoleh data, bahwa perangkat media pembelajaran yang ditampilkan cukup baik dan menyenangkan, dapat mengetahui langsung kejadian-kejadian atau peristiwa 
tentang Fisika Optik melalui media animasi, menambah wawasan dan pengalaman belajar dengan menggunakan komputer karena selama ini tidak pernah belajar seperti itu. Dua orang mahasiswa mengatakan, bahwa pembelajaran memang menyenangkan tetapi sulit dipahami karena tidak bisa bertanya kepada dosen secara langsung atau berdiskusi tentang hal-hal yang kurang dimengerti.

Hasil penelitian tersebut dapat disimpulkan, bahwa perangkat media pembelajaran berupa musik yang ditampilkan perlu dirubah agak cepat dan lebih bersemangat, tetapi tidak mengganggu pembelajaran. Respons mahasiswa pada awal pembelajaran masih belum memahami cara belajar tutorial dengan menggunakan komputer. Mereka menganggap pembelajaran tersebut sebagai ujian yang tidak boleh menanyakan kepada siapapun, sehingga suasana kelas menjadi kaku. Masalah ini akan diperbaiki pada tahap pembelajaran berikutnya siklus 2 .

2. Siklus Kedua: Ujicoba media pembelajaran Fisika Optik menampilkan materi 2, Pemantulan Cahaya, berdasarkan hasil wawancara dengan 5 orang mahasiswa diperoleh hasil akhir yang berkaitan dengan perangkat media pembelajaran dan respons mahasiswa: a) Perangkat media pembelajaran sangat menarik, materi diskusi sangat menantang untuk dipelajari dan mengadakan ujicoba. Tetapi kesulitan ketika mengerjakan soal evaluasi kalau lupa lagi materinya, tidak dapat melihat dengan segera pada komputer, tetapi harus menyelesaikan dulu soal-soal evaluasinya.b) Pembelajaran sangat menyenangkan, membangkitkan gairah belajar, menjadi penasaran dengan materi-materi selanjutnya.

Pada siklus kedua ini dapat disimpulkan, bahwa mahasiswa sudah dapat menerima dan memahami pengajaran bersifat mandiri atau tutorial dengan menggunakan komputer, hal ini terbukti dengan timbulnya rasa ingin tahu dari diri mahasiswa sendiri atau motivasi intrinsik. Program pada software komputer disetting sedemikian rupa, sehingga soal-soal evaluasi harus seluruhnya diselesaikan, dan terakhir akan muncul nilai akhir evaluasi; baru dapat kembali ke menu utama. Masalah ini akan diperbaiki pada siklus berikutnya.

3. Siklus Ketiga: Ujicoba media pembelajaran Fisika Optik menampilkan materi 3, Pembiasan Cahaya. Berdasarkan hasil wawancara dengan 5 orang mahasiswa diperoleh hasil akhir yang berkaitan dengan perangkat media pembelajaran dan 
respons mahasiswa dideskripsikan sebagai berikut: a) Perangkat media pembelajaran sangat menarik, terutama pada media animasi. Pembiasan cahaya pada benda dapat terlihat seperti pada benda aslinya. b) Pembelajaran sangat menyenangkan, membangkitkan gairah belajar, menjadi penasaran dengan materimateri selanjutnya.

Pada siklus ketiga ini dapat disimpulkan, bahwa pembelajaran dengan menggunakan media animasi dapat menunjang pemahaman mahasiswa tentang materi yang dibahas.Mahasiswa merasa sudah mendapatkan ilmu yang sesungguhnya dan bersifat kontekstual.

4. Siklus Keempat: Ujicoba media pembelajaran Fisika Optik menampilkan materi 4, Dispersi, Interferensi, dan Difraksi Cahaya. Berdasarkan hasil wawancara dengan 5 orang mahasiswa diperoleh hasil akhir yang berkaitan dengan perangkat media pembelajaran dan respons mahasiswa dideskripsikan sebagai berikut: a) Seluruh perangkat media pembelajaran sangat menarik, terutama pada media animasi. b) Pembelajaran sangat menyenangkan dan membangkitkan gairah belajar, menambah wawasan pengetahuan.

Hasil belajar mahasiswa diperoleh melalui pretes dan postes. Dari hasil pretes dengan rentang 1-100 diperoleh nilai rata-rata kelas adalah 35,29. Setelah pembelajaran menggunakan perangkat media fisika Optik dengan bantuan komputer atau model CAI, nilai rata-rata kelas postes diperoleh 70,18. Peningkatan hasil belajar ini baik secara individu maupun rata-rata kelas mengalami peningkatan yang cukup baik.

Dengan demikian, perangkat media pembelajaran dengan menggunakan model CAI dapat dianggap sempurna. Tidak ada lagi komentar mahasiswa dan tim dosen tentang perangkat media pembelajaran maupun teknik pelaksanaan.

Berdasarkan hasil analisis data, kegiatan pelaksanaan penelitian tindakan kelas berakhir sampai pada siklus keempat. Karena pada siklus ini media pembelajaran sudah diperbaiki dan dianggap layak untuk digunakan sebagai media pembelajaran fisika Optik. 


\section{KESIMPULAN}

Berdasarkan hasil analisis data dan pembahasan dapat disimpulkan, bahwa mengembangkan perangkat media pembelajaran Fisika Optik dengan menggunakan model CAI menghasilkan produk pembelajaran yang dikemas dalam bentuk CD interaktif. Isi dari perangkat media pembelajaran tersebut terdiri dari: Panduan, Materi, Profil, dan Evaluasi.

Penelitian tindakan kelas dilakukan dalam empat tahapan atau siklus, yaitu siklus pertama, siklus kedua, siklus ketiga, dan siklus keempat.Pada siklus pertama mahasiswa masih belum dapat menyesuaikan dengan kondisi model pembelajaran CAI, sehingga mereka masih mendapat kesulitan dalam memahami materi dalam media tersebut. Setelah diberikan pengertian pada siklus kedua, mahasiswa merasa sudah dapat menerima (memahami) cara belajar tutorial sehingga memberikan respon positif. Respons yang diberikan oleh mereka yaitu: perangkat media pembelajaran yang ditampilkan cukup baik dan menyenangkan, dapat mengetahui langsung kejadian-kejadian atau peristiwa tentang Fisika Optik melalui media animasi, menambah wawasan dan pengalaman belajar dengan menggunakan komputer karena selama ini tidak pernah belajar seperti itu. Perangkat media pembelajaran sangat menarik, terutama pada media animasi. Pembiasan cahaya pada benda dapat terlihat seperti pada benda aslinya. Pada siklus ketiga dan siklus keempat, perangkat media pembelajaran sudah dianggap layak untuk digunakan dalam pembelajaran fisika pada materi Optik.

Setelah mahasiswa mengikuti pembelajaran Fisika Optik dengan menggunakan perangkat media pembelajaran dengan model CAI, menunjukkan hasil belajar yang cukup baik. Selain itu dapat melatih mahasiswa untuk bekerja secara mandiri, mengatur dirinya sendiri, dan dapat membangun pengetahuannya sendiri, sehingga mahasiswa dapat melakukan self-regulated learning.

\section{DAFTAR PUSTAKA}

Arikunto, S. (1998). Prosedur Penelitian, Yogyakarta: Rineka Cipta.

Arikunto,Suharsimi. (2003). Dasar-Dasar Evaluasi Pendidikan..Jakarta: Bumi Aksara. 
Arsyad, Azhar. (2008). Media Pembelajaran. Jakarta: Raja Grafindo Persada.

Daryanto, H. (2008). Evaluasi Pendidikan. Jakarta: Rineka Cipta.

Dosen-dosen Fisika ITS. Tanpa Tahun. Fisika II. Surabaya: Institut Teknologi

Sepuluh Nopember.

Ismayati, Euis. (2009). Pengembangan Model Pengajaran Conductive untuk Meningkatkan Kemampuan Siswa Berpikir Kritis dan Bekerja Berkolaborasi Pada Pembelajaran Fisika. Disertasi tidak diterbitkan. Malang: Program Pasca Sarjana Universitas Negeri Malang.

Halliday, D \& Resnick, R. (1978). Fisika Jilid 2. Terjemahan oleh Pantur Silaban \& Erwin Sucipto. Jakarta: Erlangga.

Januar Darmawan, Ahmad. (2007).Pengembangan Media Belajar Dengan Progam macromadia Flash MX Pada Mata Diklat Membaca Dan Mengidentifikasi Komponen Elektronika di SMK. Skripsi yang tidak dipublikasikan: Universitas Negeri Surabaya.

Munadi, Yudhi. (2008). Media Pembelajaran; Sebuah Pendekatan Baru. Jakarta: Gaung Persada Press.

Pustekkom, (2005). Fisika [Online] (http://www.e-dukasi.net/mol /mo_subject.php? kls_id =1\&subject_id =1 [23 Oktober 2009].

Rochim, M. (2010). Pengembangan Media Pembelajaran dengan Model Computer Assisted Instruction (CAI) pada Materi Fisika Optik di Jurusan Teknik Elektro Universitas Negeri Surabaya. Skripsi yang tidak dipublikasikan: Universitas Negeri Surabaya.

Sadiman, Arief. dkk. (2007). Media Pendidikan. Jakarta: Raja Grafindo Persada.

Sears, Zemansky. (1991). FISIKA untuk Universitas 3. Jakarta: Binacipta

Sudjana, Nana. (1999). MetodeStatistik. Bandung: Tarsito.

Sudjana, Nana. (1989). Teknologi Pengajaran. Bandung: Sinar Baru.

Sudijono, Anas. (1995). Pengantar Evaluasi Pendidikan. Jakarta: PT Raja Grafindo Persada.

Sugiyono. (2008). Metode penelitian Kuantitatif, Kualitatif dan R\&D. Bandung: CV Alfabeta.

Sukmadinata, Nana Syaodih. (2008). Metode penelitian Pendidikan. Bandung: PT Remaja Rosdakarya.

Suryowinoto, Andi. (2008). Pengembangan Media Pembelajaran Interaktif Elektronika Digital. Skripsi yang tidak dipublikasikan: Universitas Negeri Surabaya.

Tipler, P.A. (2001). FISIKA Untuk Sains dan Teknik.Jakarta: Erlangga. 